\title{
UJI AKTIVITAS ANTIOKSIDAN EKSTRAK KELOPAK BUNGA ROSELA (Hibiscus sabdariffa L.) ASAL DAERAH SUKABUMI PROVINSI JAWA BARAT
}

\section{ANTIOXIDANT ACTIVITY OF ROSELA (Hibiscus sabdariffa L.) CALYX EXTRACTS FROM REGION OF SUKABUMI WEST JAVA PROVINCE}

\author{
Mareetha Zahra Shafirany, Iin Indawati, Intan Singgih \\ Sekolah Tinggi Farmasi Muhammadiyah Cirebon \\ Jl.Cideng Indah No. 3 Cirebon \\ Email: mareethazahras@gmail.com
}

Submitted: 21 Agustus 2021 Reviewed : 27 Agustus 2021 Accepted : 10 September 2021

\begin{abstract}
ABSTRAK
Kelopak bunga rosela mengandung senyawa bioaktif dengan kadar antosianin yang tinggi. Antosianin termasuk golongan flavonoid yang berperan sebagai antioksidan alami. Rosela merah tumbuh tersebar diseluruh Indonesia salah satunya didaerah Sukabumi yang memiliki struktur tanah dengan ketinggian 584 mdpl yang cukup untuk memenuhi syarat tumbuhnya rosela dengan baik. Tujuan penelitian ini untuk mengetahui aktivitas antioksidan dengan menggunakan pereaksi DPPH(1,1-diphenyl-2-picrylhydrazil) dengan parameter IC50. Kelopak bunga rosela diekstraksi dengan metode maserasi menggunakan pelarut etanol 70\%. Ekstrak kelopak bunga rosela dibuat dengan konsentrasi 100 ppm, 200 ppm, 400 ppm, 800 ppm, $1200 \mathrm{ppm}$ dan uji aktivitas antioksidan dilakukan dengan menggunakan spektrofotometri UV-Vis. Hasil penelitian menunjukkan IC50 ekstrak kelopak bunga rosela merah 581,5 ppm sedangkan larutan pembanding vitamin C dihasilkan nilai IC50 11,23 ppm. Kata Kunci: Ekstrak rosela, aktivitas antioksidan, DPPH, Sukabumi.

ABSTRACT

Roselle flower petals contain bioactive compounds with high levels of anthocyanins. Anthocyanins belong to the flavonoid group that acts as a natural antioxidant. Red rosella grows spread throughout Indonesia, one of which is in the Sukabumi area, which has a soil structure with a height of 584 meters above sea level, which is sufficient to meet the requirements for growing roselle adequately. The purpose of this study was to determine the antioxidant activity using DPPH(1,1-diphenyl-2-picrylhydrazil) reagent with IC50 parameter. Roselle flower petals were extracted by the maceration method using $70 \%$ ethanol as solvent. Roselle flower petal extract was made with concentrations of $100 \mathrm{ppm}$, $200 \mathrm{ppm}, 400 \mathrm{ppm}, 800 \mathrm{ppm}, 1200 \mathrm{ppm}$, and the antioxidant activity test was carried out using UV-Vis spectrophotometry. The results showed that the IC50 of the red roselle petal extract was 581,5 ppm, while the comparison for vitamin C produced an IC50 value of 11,23 ppm.
\end{abstract}

Keywords: Roselle extract, Antioxidant activity, DPPH, Sukabumi 


\author{
Penulis Korespondensi : \\ Mareetha Zahra Shafirany \\ Sekolah Tinggi Farmasi Muhammadiyah Cirebon \\ Jl.Cideng Indah No. 3 Cirebon \\ Email : mareethazahras@gmail.com
}

\title{
PENDAHULUAN
}

Tanaman rosela dapat tumbuh dengan subur pada iklim yang tropis termasuk di Indonesia. Rosela tumbuh baik di daerah yang memiliki ketinggihan tanah $584 \mathrm{mdpl}$ dan suhu antara $20-30^{\circ} \mathrm{C}$ dengan curah hujan 3.000-4.000 mm/tahun, salah satunya di Daerah Sukabumi (Diskominfo kota sukabumi, 2020). Tanaman rosela merupakan tanaman yang sangat dikenal karena kelopak bunga rosela biasa digunakan sebagai minuman kesehatan yang dapat menyembuhkan berbagai penyakit (Patel, 2014). Granul instan kombinasi ekstrak kelopak bunga rosela juga telah terbukti memiliki aktivitas untuk mengobati penyakit, termasuk hipertensi yang diujikan pada tikus putih jantan (Shafirany, et al 2018). Kelopak bunga rosela (Hibiscus sabdariffa L.) begitu popular karena hampir seluruh bagian tanaman ini dapat digunakan untuk pengobatan alternatif, selain itu rosela memiliki senyawa kimia yang dapat memberi banyak manfaat. Hal tersebut terkait beberapa kandungan yang terdapat di dalam rosela, seperti antosianin (delphinidin dan cyanidin-3-O-sambubioside), asam fenolat (khususnya asam protokatekuat), dan asam organik (asam hidroksisitrat dan asam hibiskus) (Rocha et al., 2014). Rosela (Hibiscus sabdariffa L.) merupakan tumbuhan tropis anggota Malvaceae yang memiliki kelopak berwarna merah yang memiliki kandungan antioksidan yang sangat tinggi pada kelopak bunganya (Mardiah, 2009). Antioksidan alami tersebut dapat menangkal radikal bebas, salah satunya dari antosianin yang terkandung dalam kelopak bunga rosela. Aktivitas oksidan tersebut dapat dihambat oleh senyawa antioksidan yang dapat mendonorkan elektron pada senyawa oksidan. Metode DPPH (1,1diphenyl-2-picrylhydrazil) dapat menganalisis senyawa antioksidan. Antioksidan sangat bermanfaat bagi kesehatan dalam pencegahan proses penuaan dan penyakit degeneratif. Salah satu penyebab timbulnya penyakit penyakit degeneratif dan penuaan dini karena adanya stress oksidatif dalam tubuh karena radikal bebas (Setiati, 2003). Selain itu, untuk melindungi tubuh dari serangan radikal bebas, seperti sinar UV, diperlukan antioksidan yang berfungsi untuk menstabilkan radikal bebas dengan melengkapi kekurangan elektron dari radikal bebas sehingga menghambat terjadinya reaksi berantai (Jannah dan Widodo, 2014; Purwaningsih et al, 2014). Antioksidan dapat mereduksi DPPH dengan cara memberikan atom hidrogen kepada DPPH yang merupakan senyawa radikal bebas, sehingga terjadi perubahan warna dari ungu tua menjadi kuning pucat. Selain sebagai antioksidan, antosianin juga dapat digunakan sebagai zat warna alami. Tanaman, buah-buahan, dan sayur-sayuran juga banyak mengandung antosianin (Mohamed, 2016). Penelitian yang dilakukan oleh Nadia et al (2016) aktivitas antioksidan ekstrak rosela dari daerah Nganjuk menunjukan aktivitas antioksidan ekstrak etanol bunga rosela memiliki nilai $\mathrm{IC}_{50}$ yaitu $183,9309 \mathrm{ppm}$, selain itu menurut Djaeni M. et al, (2017) aktivitas antioksidan ekstrak rosela memiliki nilai $\mathrm{IC}_{50}$ berkisar 102-69 ppm, dan menurut Inggrid, (2018) aktivitas antioksidan ekstrak rosela dari daerah Kediri ekstraksi dilakukan dengan menggunakan pelarut etanol $70 \%$ aktivitas antioksidan tertinggi ditunjukan dengan nilai $\mathrm{IC}_{50}$ yaitu $67,3 \mathrm{ppm}$. Berdasarkan latar belakang diatas maka dilakukan penelitian Penelitian ini bertujuan untuk membuktikan potensi antioksidan pada ekstrak kelopak bunga rosela merah dari daerah Sukabumi terhadap radikal DPPH yang dinyatakan dengan nilai $\mathrm{IC}_{50}$. 


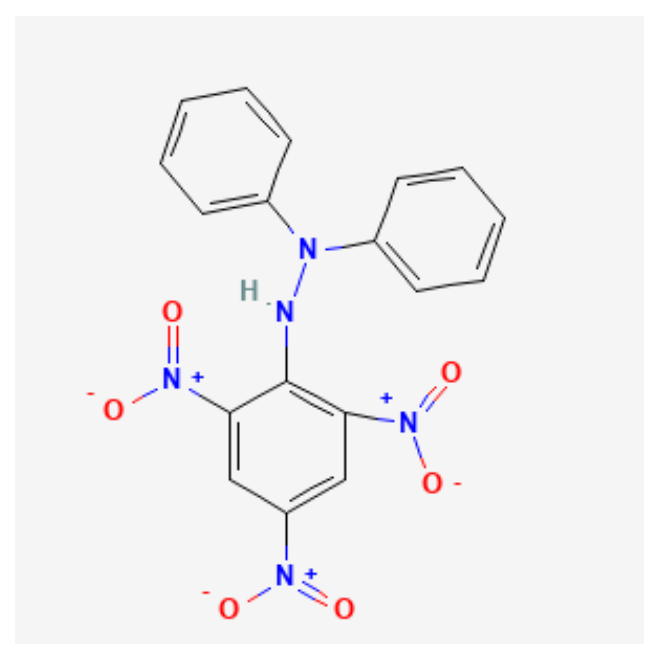

Gambar 1. Struktur DPPH (1,1-diphenyl-2-picrylhydrazil) (PubChem CID 74358)

\section{METODE PENELITIAN}

\section{Alat dan Bahan}

Alat yang digunakan dalam penelitian ini adalah neraca analitik; rotary evaporator; spektroforometri UV-vis; timbangan analitik; waterbathh; batang pengaduk; botol vial; bejana maserasi; cawan porselen; corong pisah; gelas kimia (pyrex); gelas ukur (pyrex); kertas saring whatman no 1; labu ukur (pyrex).

Bahan pada penelitian ini adalah kelopak bunga rosela merah (Hibiscus sabdariffa L.); aquadest (pro teknis CV Bratachem); DPPH; Vitamin C ; etanol 70\%.

\section{Jalannya Penelitian}

1. Pengumpulan Bahan

Bahan yang digunakan adalah simplisia kelopak bunga rosela (Hibiscus sabdariffa

L.) didapat dari Daerah Jampang Kulon, Kecamatan Sukabumi.

2. Pengamatan Organoleptis Kelopak Bunga Rosela Merah.

Uji organoleptis dilakukan dengan mengamati warna, bau dan bentuk kelopak bunga rosela.

3. Pembuatan Ekstrak

Simplisia kelopak bunga rosela (Hibiscus sabdariffa L) dimaserasi menggunakan etanol $70 \%$ selama 24 jam dengan pengulangan sebanyak 2 kali sambil sesekali diaduk. Hasil maserasi disaring dan dikumpulkan, kemudian dipekatkan dengan rotary evaporator hingga kental dan kembali dipanaskan pada waterbath suhu $40^{\circ} \mathrm{C}$ sehingga didapat bobot tetap dan dihitung randemen ekstrak (Depkes RI, 2011).

\section{Uji Aktivitas Antioksidan Dengan Metode DPPH}

a. Persiapan Awal

i. Pembuatan Larutan DPPH 400 ppm

Timbang DPPH sebanyak $40 \mathrm{mg}$ tambahkan dengan etanol 70\% sehingga $100 \mathrm{ml}$ (400 ppm) kocok sampai homogen (Brand Williams, 1995).

\section{ii. Larutan Blanko}

Pipet $4 \mathrm{ml}$ etanol $70 \%$ menggunakan pipet volum masukan ke dalam vial dan campurkan $4 \mathrm{ml}$ larutan DPPH kemudian kocok sampai homogen. Diinkubasi pasa suhu $30^{\circ} \mathrm{C}$ selama 30 menit ditempat gelap.

iii. Pembuatan Larutan Induk Vitamin C 100 ppm

Untuk kontrol positif digunakan antioksidan standar vitamin $\mathrm{C}$ dengan perlakuan yang sama seperti sampel. Timbang $10 \mathrm{mg}$ vitamin C 
ditambahkan dengan etanol $70 \% 100 \mathrm{ml}$ (100 ppm) dikocok sampai homogen.

iv. Pembuatan Larutan Uji Vitamin C

Membuat larutan vitamin $\mathrm{C}$ dengan konsentrasi 4 ppm, 6 ppm, 8 ppm, 12 ppm, 14 ppm dengan cara mengencerkan larutan induk vitamin $\mathrm{C}$ masingmasing $2 \mathrm{ml}, 3 \mathrm{ml}, 4 \mathrm{ml}, 6 \mathrm{ml}$, dan $7 \mathrm{ml}$ ditambahkan etanol 70\% hingga 50 ml. (Pandanwangi S. 2018).

v. Pembuatan Larutan Induk Ekstrak Kelopak Bunga Rosela Merah $2000 \mathrm{ppm}$

Timbang $200 \mathrm{mg}$ ekstrak kelopak bunga rosela merah ditambah etanol 70\% $100 \mathrm{ml}$ dikocok sampai homogen.

vi. Pembuatan Larutan Uji Ekstrak Bunga Rosela Merah

Membuat larutan ekstrak bunga rosela merah dengan konsentrasi 100 ppm, 200 ppm, 400 ppm, 800 ppm, 1200 ppm dengan mengencerkan masingmasing 2,5 ml; $5 \mathrm{ml} ; 10 \mathrm{ml} ; 20 \mathrm{ml} ; 30 \mathrm{ml}$; larutan induk ditambahkan etanol $70 \%$ sebanyak $50 \mathrm{ml}$ (Nadia et al 2016).

b.Pengujian Aktivitas Antioksidan

i. Penentuan panjang gelombang maksimum

Larutan blanko ditentukan serapannya menggunakan spektrofotometri UVVis diukur dengan panjang gelombang $400-700 \mathrm{~nm}$ serta ditentukan paling panjang gelombang maksimum dengan melihat absorbansi yang besar.

ii. Pengujian aktivitas antioksidan vitamin $\mathrm{C}$ dan sampel ekstrak rosela

Larutan vitamin $C$ konsentrasi 4 ppm, 6 ppm, 8 ppm, 12 ppm, 14 ppm, masing-masing diambil sebanyak $4 \mathrm{ml}$ ditambahkan $4 \mathrm{ml}$ larutan DPPH dikocok sampai homogen. Larutan ekstrak kelopak bunga rosela merah dengan konsentrasi 100 ppm, 200 ppm, 400 ppm, 800 ppm, 1200 ppm, masing-masing diambil sebanyak $4 \mathrm{ml}$ ditambahkan $4 \mathrm{ml}$ larutan DPPH dikocok sampai homogen. Vitamin $\mathrm{C}$ dan sampel ekstrak rosela di inkubasi sampai 30 menit pada suhu $30^{\circ} \mathrm{C}$ kemudian di baca absorbansinya pada setiap pengujian dilakukan penetapan serapan blanko.

iii. Perhitungan aktivitas antioksidan

Uji aktivitas antioksidan data dianalisis menggunakan rumus persamaan regresi linier $(\mathrm{y}=\mathrm{bx}+\mathrm{a})$ sehingga diperoleh nilai $\mathrm{IC}_{50}$. Aktivitas antioksidan ditentukan berdasarkan besarnya serapan radikal DPPH oleh sampel melalui perhitungan persentase inhibisi dengan menggunakan rumus :

$$
\% \text { inhibisi }=\frac{\text { Nilai serapan DPPH }- \text { nilai serapan ekstrak }}{\text { Nilai searapan DPPH }} \times 100 \%
$$

Selanjutnya dilakukan perhitungan $\mathrm{IC}_{50}$ yang merupakan konsentrasi sampel untuk dapat meredam $50 \%$ aktivitas radikal DPPH. Nilai $\mathrm{IC}_{50}$ diperoleh dari perpotongan garis antara 50\% daya inhibisi dengan konsentrasi sampel. Daya aktivitas antioksidan peredaman radikal bebas DPPH dianalisis masing-masing dihitung nilai $\mathrm{IC}_{50}$ menggunakan analisis regresi linier. Hasil perhitungan dimasukkan ke dalam persamaan regresi $(y=a+b x)$ dengan konsentrasi ekstrak (ppm) sebagai absis (sumbu $x$ ) dan nilai \% peredaman (antioksidan) sebagai kordinatnya (sumbu $y$ ). Persamaan tersebut digunakan untuk menentukan IC50 masing-masing sampel dinyatakan dengan nilai y sebesar 50 dan nilai x yang diperoleh sebagai IC50 (Rahmayani et al, 2013) 


\section{Analisis Data}

Aktivitas antioksidan di ukur dengan menggunakan spektrovotometer UV-Vis, kemudian data yang diperoleh disajikan dalam bentuk tabel. Pembanding yang digunakan sebagai kontrol positif adalah vitamin $\mathrm{C}$, digunakan sebagai pembanding karena berfungsi sebagai antioksidan sekunder yaitu menangkap radikal bebas, mencegah terjadinya reaksi berantai, aktivitas antioksidannya sangat tinggi, mudah diperoleh dan vitamin C lebih polar dari vitamin yang lain (Isnindar, 2011).

\section{HASIL DAN PEMBAHASAN}

\section{Hasil pengumpulan bahan dan pembuatan ekstrak}

Pengumpulan bahan dan pembuatan ekstrak kelopak bunga rosela asal daerah sukabumi didapatkan hasil seperti yang tertera pada Tabel 1.

Tabel 1 menunjukan hasil rendemen dari 129 gram dengan nilai rendemen 25,8\%. Hasil ini memenuhi persyaratan Farmakope Herbal Indonesia, bahwa rendemen ekstrak kelopak bunga rosela tidak kurang dari 19,70\% (Depkes RI, 2011). Apabila jumlah rendemen semakin besar maka jumlah senyawa aktif yang terkandung dalam sampel juga semakin banyak. Tingginya senyawa aktif yang terdapat paada suatu sampel ditunjukan dengan tingginya jumlah rendemen yang dihasilkan (Harbone, 1987).

\begin{tabular}{cccc}
\hline Sampel & Bobot Simplisia (g) & Bobot Esktrak (g) & (\%) Randemen \\
\hline $\begin{array}{c}\text { Kelopak Bunga Rosela asal } \\
\text { Sukabumi }\end{array}$ & 500 & 129 & 25,8 \\
\hline
\end{tabular}

Tabel 1. Hasil Pengumpulan Bahan dan Pembuatan Ekstrak

\section{Hasil Pengujian Aktivitas Antioksidan}

Penentuan panjang gelombang serapan maksimum panjang gelombang serapan maksimum dilakukan pada spektrofotometri UV-Vis pada rentang antara $400 \mathrm{~nm}-700 \mathrm{~nm}$ dan didapatkan hasil Panjang gelombang maksimun yaitu sebesar $524 \mathrm{~nm}$. Penentuan panjang gelombang pada saat senyawa yang ingin diukur memberikan absorbansi yang paling optimum merupakan tujuan penentuan panjang gelombang serapan maksimum. Hasil pengujian aktivitas antioksidan ekstrak kelopak bunga rosela asal daerah Sukabumi yang dilakukan dengan menggunakan metode DPPH dan sebagai standar digunakan vitamin C. Hasil pengujian dapat dilihat pada Tabel 2.

Tabel 2. Hasil pengujian aktivitas antiosidan $\left(\mathrm{IC}_{50}\right)$

\begin{tabular}{ccccccc}
\hline Sampel & $\begin{array}{c}\text { Konsentrasi } \\
(\mathbf{p p m})\end{array}$ & \multicolumn{2}{c}{ Absorbansi } & \%inhibisi & $\begin{array}{c}\text { Persamaan } \\
\text { Regresi Linier }\end{array}$ & IC $_{\mathbf{5 0}}(\mathbf{p p m})$ \\
\hline Vitamin C & 4 & 1,280 & 1,091 & $14,76 \%$ & & \\
& 6 & 1,280 & 0,985 & $23.04 \%$ & $50=5,085 \mathrm{x}-7,121$ & 11,23 \\
& 8 & 1,280 & 0,889 & $30,54 \%$ & & \\
& 12 & 1,280 & 0,554 & $56,71 \%$ & & \\
Ekstrak & 14 & 1,280 & 0,472 & $63,12 \%$ & & \\
Kelopak Bunga & 100 & 1,280 & 1,266 & $1.093 \%$ & & \\
Rosela asal & 200 & 1,280 & 0,929 & $27,42 \%$ & $50=0,068 \mathrm{x}+10,476$ \\
Sukabumi & 800 & 1,280 & 0,652 & $49,06 \%$ & & \\
& 1200 & 1,280 & 0,275 & $78,51 \%$ & & \\
& 1,280 & 0,253 & $80,23 \%$ & & \\
\hline
\end{tabular}


Tabel 3. Sifat antioksidan berdasarkan nilai $\mathrm{IC}_{50}$

\begin{tabular}{cc}
\hline Konsentrasi & Keterangan \\
\hline$<100 \mathrm{ppm}$ & Sangat aktif \\
$100 \mathrm{ppm}-1000 \mathrm{ppm}$ & Aktif \\
$1000 \mathrm{ppm}-5000$ & Rendah \\
$\mathrm{ppm}$ & \\
$<5000 \mathrm{ppm}$ & Tidak aktif \\
\hline
\end{tabular}

Uji aktivitas antioksidan ekstrak kelopak bunga rosela merah (Hibiscus sabdariffa L.) dilakukan dengan menggunakan metode DPPH (1,1-diphenyl-2picyhidrazyl). Metode DPPH dipilih karena dapat stabil dalam mengevaluasi perendaman radikal bebas pada bahan alam. Warna dpph akan berubah dari violet menjadi kekuningan karena terjadi proses donasi hydrogen elektron sehingga dpph akan tereduksi, jumlah donasi elektron yang sebanding dengan perubahan warna diikuti penurunan absorbansi DPPH (Dris et al, 2004).

Nilai presentasi penghambatan radikal bebas (\% inhibisi) dapat ditentukan dari nilai absorbansi DPPH yang diperoleh. Selanjutnya nilai \% inhibisi dapat menentukan nilai $\mathrm{IC}_{50}$. Nilai $\mathrm{IC}_{50}$ merupakan bilangan yang menunjukkan konsentrasi ekstrak (ppm) yang mampu menghambat proses oksidasi sebesar 50\%. Semakin tinggi aktivitas antioksidan artinya semakin kecil nilai $\mathrm{IC}_{50}$. Nilai $\mathrm{IC}_{50}$ diperoleh dari persamaan regresi linier yaitu antara konsentrasi dan \% inhibisi diplotkan sebagai fungsi $\mathrm{x}$ dan $\mathrm{y}$.

Pada hasil pengukuran menunjukan bahwa absorbansi yang dihasilkan semakin menurun karena dengan adanya peningkatan konsentrasi larutan. Absorbansi yang dihasilkan semakin kecil menyebabkan perubahan warna pada DPPH karena semakin tinggi konsentrasi larutan semakin banyak senyawa antioksidan menjadi donor eloktron atau radikal elektron dari DPPH. Semakin kecil nilai IC $_{50}$ maka semakin kuat pula aktivitas antioksidan senyawa tersebut. Berdasarkan hasil diatas didapatkan hasil bahwa seluruh sampel menunjukan ekstrak kelopak bunga rosela asal Sukabumi memiliki aktivitas antioksidan yang aktif/kuat dengan nilai $\mathrm{IC}_{50} 581,5 \mathrm{ppm}$ meskipun jika dibandingkan dengan vitamin $\mathrm{C}$ memiliki hasil aktivitas antioksidan yang sangat aktif/kuat dengan nilai $\mathrm{IC}_{50} 11,23 \mathrm{ppm}$. Berbeda dengan penelitian yang telah dilakukan oleh Maria inggrid, dkk, 2018 aktivitas antioksidan yang dimiliki oleh ekstrak etanol kelopak bunga rosela 67,3 ppm yang termasuk dalam katagori antioksidan sangat kuat.

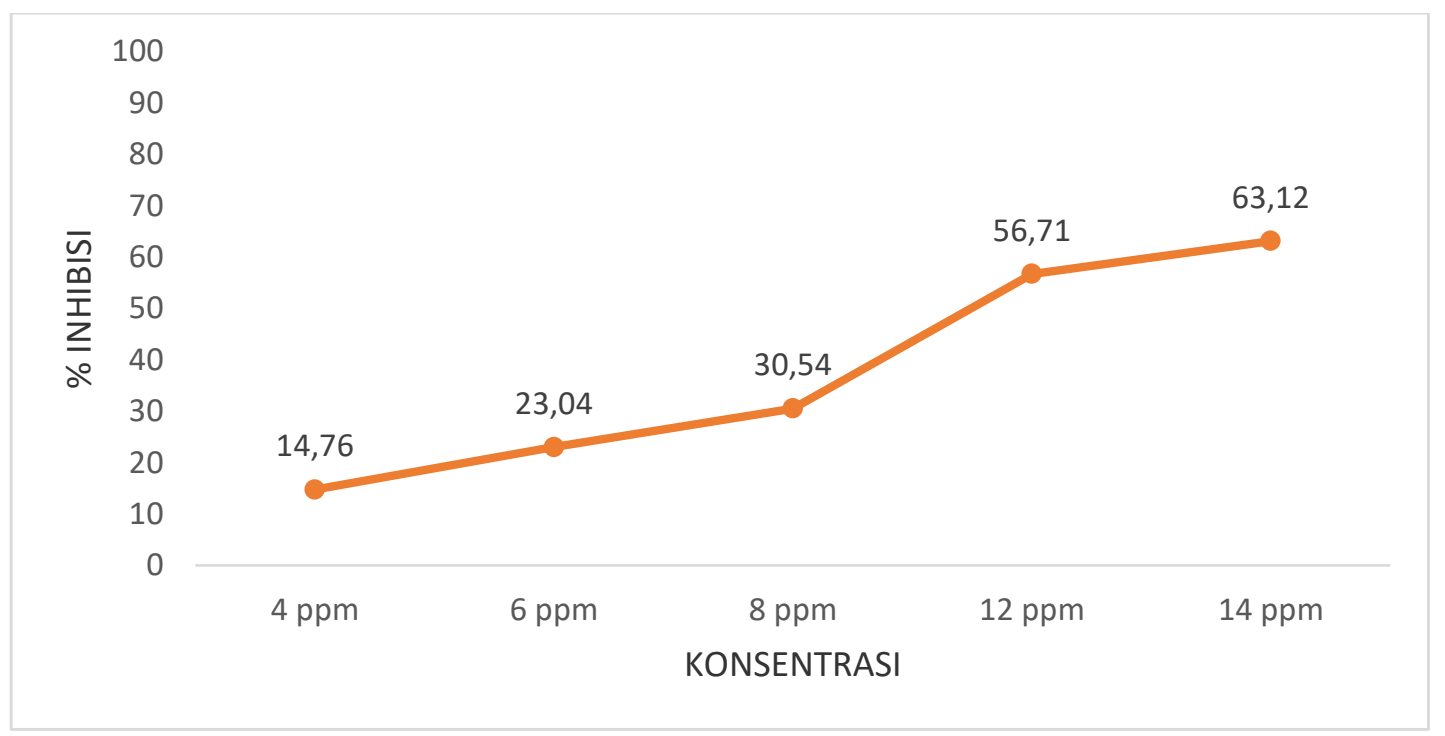

Gambar 2. Hasil Uji antioksidan Vitamin C 


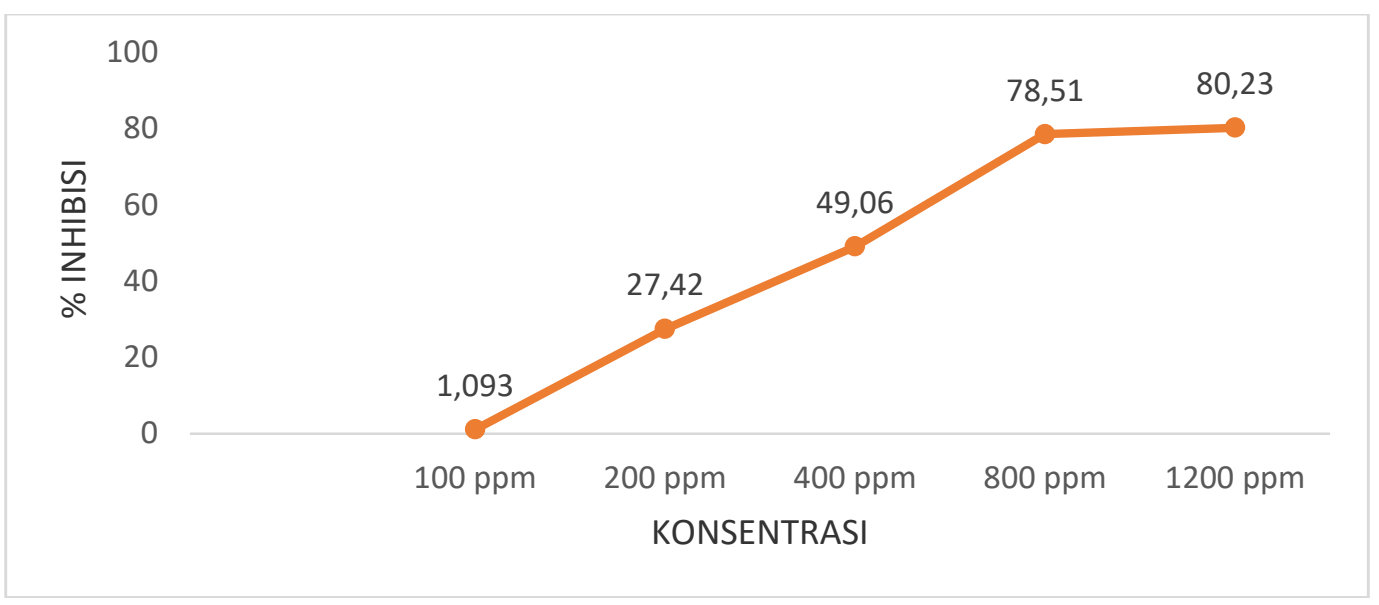

Gambar 3. Hasil Uji Antioksidan Ekstrak Kelopak Bunga Rosela asal daerah Sukabumi

Perbedaan nilai IC50 pada rosela asal daerah Sukabumi dapat dipengaruhi oleh beberapa faktor. Salah satu faktor yang dapat mempengaruhi adalah kandungan senyawa pada ekstrak kelopak bunga rosela tersebut. Perbedaan aktivitas antioksidan bisa disebabkan beberapa hal meskipun pada dasarnya tumbuhan tersebut berasal dari genus yang sama. Perbedaan aktivitas antioksidan bisa dikarenakan tempat tumbuh, metode pengolahan, dan umur tanaman yang dapat mempengaruhi secara objektif dan karakterisasi sensoris. Umur tanaman yang sudah lebih tua memiliki pengaruh yang sangat nyata terhadap total fenol tumbuhan, total flavonoid dan aktvitas antioksidan (Felicia, Widarta and Yusasrini, 2017). Faktor lain yang dapat mempengaruhi hal tersebut adalah lokasi tempat tumbuh. Salah satunya adalah faktor ketinggian tanah diatas pemukaan laut. Tanaman rosela tumbuh optimal di daerah dengan ketinggian 600 mdpl. Sukabumi termasuk daerah dataran tinggi. Daerah dataran tinggi atau pegunungan memiliki curah hujan yang lebih tinggi dengan suhu yang lebih rendah dan kecepatan penguraian bahan organik dan pelapukan mineral berjalan lebih lambat. Oleh karena itu di daerah dataran tinggi atau pegunungan tanahnya relatif lebih subur, kaya bahan organik dan unsur hara. Tinggi tempat berpengaruh terhadap suhu udara dan intensitas cahaya. Suhu dan intensitas cahaya akan semakin kecil dengan semakin tingginya tempat tumbuh. Cahaya berpengaruh langsung pada ketersediaan makanan. Klorofil dibentuk dari hasil fotosintesis dan berpengaruh secara langsung terhadap pertumbuhan setiap organ atau terhadap keseluruhan tumbuhan (Saida et al, 2016). Rosela juga dapat tumbuh didaerah tropis dan subtropis dengan suhu rata-rata $24-32^{\circ} \mathrm{C}$. Namun rosela masih toleran pada kisaran suhu $10-36^{\circ} \mathrm{C}$. Untuk menghasilkan pertumbuhan dan perkembangan yang optimal, rosela memerlukan waktu 4-5 bulan dengan suhu malam tidak kurang dari $21^{\circ} \mathrm{C}$ (Mardiah dkk, 2009). Sampel yang digunakan berasal dari daerah Sukabumi yang berada di ketinggian $584 \mathrm{mdpl}$ dan juga memiliki suhu $25^{\circ} \mathrm{C}$ sehingga daerah tersebut merupakan daerah yang optimal jika ditanami oleh tanaman rosela dilihat dari data ketinggian dan suhunya (Badan Pusat Statistik, 2018).

\section{KESIMPULAN}

Dari hasil penelitian uji aktivitas ekstrak kelopak bunga rosela merah (Hibiscus sabdariffa L) asal daerah sukabumi memiliki aktivitas antioksidan kuat dengan nilai $\mathrm{IC}_{50}$ aktivitas antioksidan yang terkandung dalam ekstrak kelopak bunga rosela merah asal Daerah Sukabumi yakni sebesar $581,5 \mathrm{ppm}$.Hal ini karena sampel yang digunakan berasal dari daerah Sukabumi berada di ketinggian $584 \mathrm{mdpl}$ dan juga memiliki suhu $25^{\circ} \mathrm{C}$ sehingga daerah tersebut merupakan daerah yang optimal jika ditanami oleh tanaman rosela dilihat dari data ketinggian dan suhunya. 


\section{DAFTAR PUSTAKA}

Badan Pusat Statistik. 2018. Rata-rata Suhu dan Kelembaban Udara Menurut Bulan di Kabupaten Boyolali, 2016. https://boyolalikab.bps.go.id/statictable/2018/11/19/232/ rata-rata-suhu-dan-kelembaban-udara-menurut-bulan-di-kabupaten-boyolali-2016. html.

Departemen Kesehatan RI. 2011. Suplemen II Farmakope Herbal Indonesia. Departemen Kesehatan RI Jakarta: 174-175

Diskominfo kota sukabumi, 2020. Portal Resmi kota Sukabumi. Portal Resmi Kota Sukabumi. https:// portal. Sukabumikota.go.id/geografis/

Djaeni, M., Ariani, N., Hidayat R., Utari, F. D., 2017, Ekstrak antosianin dari Kelopak Bunga Rosela (Hibiscus sabdariffa L.) Berbantu Ultrasonik: Tinjauan Aktivitas Antioksidan . Jurnal Aplikasi Teknologi Pangan 6 (3). 148-151

Dris, R. And Jain, S.M., 2004, Production Practices and Quality Assexment of Food Crops: Quality Handling and Evaluation,kluwer Academic Publisher, New York, pp. 58-60

Erianto, 2009. Budidaya Rosela

Felicia, N., Widarta, I. W. R. and Yusasrini, N. L. A. 2017. Pengaruh ketuaan daun dan metode pengolahan terhadap aktivitas antioksidan dan karakteristik sensoris teh herbal bubuk daun alpukat, Ilmu dan Teknologi Pangan, 5(2), pp. 85-94.

Harborne, J.B., 1987. Metode Fitokimia, Edisi ke dua, ITB, Bandung.

Inggrid. Maria., Hartanto Yansen., Widjaja Jesslyn Fedora. Program Studi Teknik Kimia, Fakultas Teknologi Industri, Universitas Katolik Parahyangan: Bandung

Isnindar. 2011. Isolasi dan Identifikasi Senyawa Antioksidan Daun Kesemek (Diopyroskaki Thunb) dengan Metode DPPH. Majalah Obat Tradisional. 16 (3) : 157-164.

Jannah, R., dan Widodo. "Ekspresi Protein P53 pada Sel TIG -3 Setelah Perlakuan Sinar UV dan Ekstrak Biji Juwet (Syzygium cumini)", Jurnal Biotropika. (Volume 2 No 5, 2014) 273-275.

Kim, D. K., Lee, K. W., Lee, H. J., and Lee, C. Y., Vitamin C Equivalent Antioxidant capacity (VCEAC) of Phenolic Phytocemicals, J. Agric. Food Chem 2002; 50: 37133717.

Mardiah. (2009): Budidaya dan Pengolahan Rosella Si Merah Segudang Manfaat. Jakarta: Agromedia Pustaka.

Maria Inggrid, Yansen Hartanto dan Jesslyn Fedora Widjaja, Karakteristik Antioksidan pada Kelopak Bunga Rosella (Hibiscus sabdariffa Linn.), Jurnal Rekayasa Hijau (2018) Vol 2 No 3, pp 283-289

Mohamed, Rasha K. et al., 2016. Extraction of anthocyanin pigments from Hibiscus sabdariffa L. and evaluation of their antioxidant activity. Middle East Journal of Applied Sciences, vol 6,pp. 856-866

Nadia, S., Rianti., \& Nirmala, R. 2016. Uji aktivitas Antioksidan Kombinasi Dari Kulit Buah Naga (Hylocereus costaricensis) dan Bunga Rosela (Hibiscus sabdariffa L.) dengan Metode DPPH (1,1 Diphenyl-2-picrylhidrazyl) Beserta Bentuk Tunggalnya. Jurnal KesMaDaSKa. 94-99.

Patel, S. 2014. Hibiscus sabdariffa: an ideal yelunderexploited candidale for Neutraceutrical application. Biomedician dan Preventative nutrition vol 4

Pelarut yang Berbeda terhadap Metode DPPH (Diphenyl Picril Hidrazil). Journal Of Marine Research. Volume 2, Nomor 4, 36-45

Purwaningsih, S., Salamah, E., dan Budiarti, T., A. "Formulasi Skin Lotion dengan Penambahan Karagenan dan Antioksidan Alami dari Rhizophora mucronata Lamk". Jurnal Akuatika. (Volume V No 1, 2014) 55-62. 
Rahmayani, U., Delianis Pringgenies, Ali Djunaedi. 2013. Uji Aktivitas Antioksidan Ekstrak Kasar Keong Bakau (Telescopium telescopium) dengan

Rocha, I., Bonnleader, B., Sievers, H., dan Heinrich, M. (2014): Hibiscus sabdariffa L. A Phytochemical and Pharmacological Review. J Food Chem. 165, 424-443.

Saida I. Suradji1, Ahmad Najib, Aktsar Roskiana Ahmad. Studi Komparasi Kadar Flavonoid Total Pada Bunga Rosella Merah (Hibiscus sabdariffa L.) Asal Kabupaten Luwu Utara Provinsi Sulawesi Selatan dan Kabupaten Kediri Provinsi Jawa Timur. Jurnal Fitofarmaka Indonesia, Vol. 3 No. 2

Shafirany M.Z. , Susilawati Y. , Muhtadi A., Milanda T. Chaerunissa A.Y. 2018. Antihypertensive Activities Instant Granul of Combination Extract Roselle Flower Petals (Hibiscus sabdariffaL.), Chayote Fruit (Sechium edule (Jacq.) Sw.) and Aloe Vera Leaves (Aloe Vera L.) in White Male Rats. Res. J. Chem. Environ. Vol 22 (Special Issue I).

Setiati S.Radikal bebas, antioksidan, dan proses menua. Tinjauan Pustaka. Medika 2003; 6:366-9. 
